\title{
VOORBEELD VAN ANTWOORDE ONTVANG VAN 'N HOORDER I.V.M. DIE PREDIKING
}

\section{Inhoudelik}

1.1. Wat verwag $u$ as hoorder van 'n preek? Skrifuitleg en toepassing in huidige situasie.

1.2. Hoe beoordeel $u$ die preke wat $u$ hoor in die lig van 1.1. hierbo? 1) Of Skrif uitgelê word (Eksegeties). 2) Of kontemporêre boodskap volgens verband deurgegee word.

1.3. Kry $\mathrm{u}$ die indruk dat erns gemaak is met die studie en voorbereiding van die preek en dat eerlik gepoog word om die te verklaar? Alleen in sommige gevalle.

1.4. Word die Nuwe Testament vanuit die Ou Testament belig en vanaf die Ou Testament na die Nuwe Testament gekom of word daar 'n direkte gelykskakeling tussen die O.T.-situasie en ons eie situasie gemaak? Ja vir eerste deel van vraag. Nee vir tweede deel.

1.5. Indien $\mathrm{u}$ sonder reserwe met dominees kon praat, watter raad sou $\mathrm{u}$ aan hulle wou gee? 1. Wees aktueel. 2. Wees besield en oortuigend. 3. Wees beskeie.

\section{Stofkeuse}

2.1. Hoedanig varieer die stofkeuse vir die prediking. (Word bv. afwisselend uit die O.T. en N.T. gepreek; word historiese- en profetiese stof afwisselend behandel ens.)? Planmatigheid ontbreek dikwels. Afwisseling wel goed.

2.2. Maak die tekskeuse 'n beplande of lukraak indruk? Nee.

\section{Aktualiteit}

3.1. Watter fokus het die prediking wat $u$ hoor. (Is die fokus bv. eng in die sin dat dit net fokus op die kerklike lewe; kerkbesoek, bydraes, ens. of op die persoonlike voorkeure en beklemtoninge van die prediker, of word die hele linie van die geloofslewe in fokus geneem, ook die sport en sakelewe.) Evalueer asseblief openhartig. Beklemtoninge van prediker druk groot stempel af, bv. terneergedruktheid. Hele linie selde in drukte beplanning inbegryp.

3.2. Hoedanig motiveer die preke wat $u$ hoor $u$ vir $u$ christenskap in die week? Oor algemeen tot positiewe uitlewing en belydenis.

3.3. Wat is $u$ eerlike diagnose oor die relevansie van die preek? Redelik - maar tog ver van praktiese lewe soms af.

3.3.1. Hou dit vir $u$ persoonlik 'n boodskap in van hart tot hart en voel u betrokke by die preek? Soms as preek nie te lesingagtig en onbesield is nie.

3.3.2. Hoe raak die preek $u$ gesin in sy differensiasie (bv. man en vrou se behoeftes; gerigtheid op die behoeftes van die jeug, bejaardes, ens.)? Moeilike vraag! Sommige preke wel raak.

3.3.3. Bespeur $u$ 'n aanvoeling by die prediker vir die mens van 
ons tyd en sy (pastorale) probleme? Te weinig profetiese bewoënheid.

3.3.4. Wat beskou $u$ as die besondere probleme van ons tyd wat u graag in die prediking betrek wil hê? „Outsider"-houding, vermaakjag, geldsug, koudheid.

3.3.5. Wat is $u$ beskouing as hoorder oor die moderne gedagtes t.o.v. aktueler prediking, bv. die dialogiese metode (d.w.s. dat die prediker in sy preek ook vrae stel wat leef in die harte van die hoorders; dat hy in lyn met die moderne lewensgevoel meer soekend preek as ,aanseggend"); op die jeug gerigte prediking; diskussie na die diens oor die preek; Bybelstudie i.p.v. prediking, ens.? Dialogiese metode goed as dit net swak probleme aan die orde stel. Verswyging van prediking. Nee.

3.3.6. Hoe meen u kan die prediker die gevaar vermy om die hoorders in sy prediking aanstoot te gee deur 'n houding van ,afstand", "heilig wees", afsydigheid ens. 1. Natuurlike wyse van optrede. 2. „Ons" eerder as „u". 3. „Julle" en ,jy” in onpersoonlike vorme gebruik.

\section{Formeel}

4.1. Word die preek logies en as 'n afgeronde eenheid gebring? Deurgaans ja.

4.2. Wat is $u$ mening oor die taalgebruik van predikante in die prediking in terme van die volgende leidinggewende woorde: predikantetaal, teologiese vaktaal, kanseltaal, tale Kanaäns, cliches, ens.? Taalgebruik goed. Meer moderne uitdrukkinge kan gebruik word.

4.3. Watter kenmerke, meen $\mathrm{u}$, moet die taal vir die prediking hê en watter gevare moet vermy word? Eenvoudig, seggend, beeldryk.

4.4. Is daar sekere tipiese predikantshoudinge en -maniere wat in die prediking na vore kom en vir $u$ as hoorder lastig is? Indien wel, noem dit asseblief. Hande in broeksakke. Eentonige gestikulasie. Stadig praat.

4.5. Is die preke wat $u$ hoor te kort of te lank en is dit bevatlik ook vir die kinders en jeug? Soms te langdradig.

4.6. Indien daar enigiets is wat $u$ as hoorder wil byvoeg, kan $u$ dit hier doen. 1. Aanloop tot teks in inleiding oor algemeen nie aandag-pakkend nie. 2. Voordrag word skynbaar baie afgeskeep. 